\title{
Scuba Diving Experience Fun Recognition and Its Impact on Self- Realization - Focusing on Middle and High School Students
}

\author{
Hye-Kyung Baek ${ }^{1}$ and Hwa-yeol Choi ${ }^{2 *}$ \\ ${ }^{1}$ Professor, Department of Sports Industry, Jeju International University., Jeju-si, \\ Jeju-do, South Korea \\ 2*Professor, Department of Aviation Service Management Jeju International \\ University, South Korea \\ 1jean_78@hanmail.net, 2*hwayeol@hanmail.net
}

\begin{abstract}
In this study, how scuba diving experiences within the restricted waters of middle and high school students affect their awareness of fun. It reveals various variables on the perception of fun that can encourage continued participation in scuba diving. Discuss the relationship between marine activities scuba diving and fun awareness and self-realization. In summary, the results are as follows: First, we verified the hypothesis, (H1) that scuba diving experiences of middle and high school students will have a positive effect on the recognition of fun. The scuba diving experience was found to have a significant positive, (+) effect on interest and recognition, which is one of the fun perceptions. However, it was found that the entertainment experience had a significant positive, (+) effect on social recognition of fun. Second, as a result of testing the hypothesis, (H2) that the marine activity will have a positive effect on self-realization, it was found to be significant. Third, as a result of verifying, (H3) that fun perception will have a positive, $(+)$ effect on self-realization, it was found that it was significant, (+). Given these results, it suggests that scuba diving experiences need to be improved, space development with optimal experience considering middle and high school students, and efforts by the competent leadership training industry.
\end{abstract}

Keywords: Scuba diving, Fun recognition, Self-realization, Marine sports

\section{Introduction}

The industry in the 21 st century is growing at a high rate every year, with the most pronounced growth trend being the oceans [1]. Recently, the marine-centered class has been on the rise [2], and the government has been establishing 10 regional marine development plans in the 10-year Basic Plan for Marine Development, (OK21), including the implementation plan for the marine sector. Korea, the Ministry of Maritime Affairs and Fisheries is expanding its infrastructure to foster marine and sector based on the basic maritime promotion plan and detailed implementation plan for marine promotion [3]. Against this backdrop, it can be seen as a central increase in elements, an adventure that can be creative and thrilling, and a fulfillment of a desire for a new role, beyond physical activity for personal health, along with an increase in national income. However, although it is suggested [4] that the share of domestic marine industries will increase from $26 \%$ in 2006 and $31.4 \%$ in

Article history:

Received (June 8, 2020), Review Result (July 14, 2020), Accepted (August 16, 2020) 
2010 to $40.8 \%$ in 2020 , it is true that the value of the ocean for leisure is insufficient and that maritime police, including the ocean, are still weaker than that of Southeast Asia. Scuba diving, one of the marine sports, became popular in 2012 as it contains various experience elements that cannot be felt on the ground under buoyancy with breathing equipment in water. The number of Koreans working for scuba diving associations established at home and abroad is estimated to be more than 250,000 [5]. Scuba diving is recognized as a sport that cannot be experienced without special equipment in human body structure. A study in scuba diving involves scuba diving and the ability of leaders [6][7][8] and the research related to the capabilities of the leaders [9][10]. Recently, studies related to scuba diving experiences and experiences [11][12][13] have been reported, but partial research is aimed at adults and research on middle and high school students is hard to find. Therefore, we would like to find out how the marine type scuba diving experience has a sense of fun and self-realization for middle and high school students, and further propose policy previews for middle and high school students to participate in marine activities.

\section{Theoretical background}

\subsection{Experience of marine leisure}

A marine tourism is an activity [14] that performs marine recreational activities on land and sea due to shorelines, which can be defined differently depending on goals, space and behavior. First, the goal is defined as an activity that seeks change away from daily life, and secondly, the space is interpreted as an activity of a goal occurring in a community on the sea and coast. Finally, in terms of behavior, it can be defined as directly or indirectly dependent on or associated with marine space. Such ocean demand is spreading from beaches that used to be centered around beaches to oceans such as yachts, ship fishing, jet skiing, water skiing, wake boarding, and skin scuba. Ocean means the form of activities carried out in the ocean using water as a medium and differs from general activities or sports in that the purpose of activities varies according to individual tastes and personalities, such as improving individual health and fitness, healthy leisure and social activities [15]. The ocean can be seen as a leisure activity requiring extreme experience and experience, whether directly involved or viewed, and in 1990 the increase in economic growth and leisure time changed desires, thereby expanding new demand, while at the same time changing subdivisions, diversification and high-flowers [16]. The ocean has established itself as an activity that will lead the 21 st century with excellence in educational value as an experience education utilizing nature, along with the physical health and emotional purification and stress relief of those who have a desire for new attempts [2][17]. In general, experience and experience are mixed and used. Experience refers to the knowledge or information emotion gained in any activity and is known to serve as a kind of intrinsic reward for the psychological response that appears during the act [18]. However, as part of the experience, experience refers to the process directly experienced in the place) [19], which is not simply viewed, but actually seen, heard, and experienced, which translates into total knowledge or dexterity gained in the process and implies a high number of intervention in the experience [20]. In behavioral research, experience can be seen as a very important concept, as it plays a role in understanding the motivation, which is the general paradigm of behavioral research, and satisfaction, which is the subsequent evaluation stage. This is because activities create value through the consumer's direct experience, recognize satisfaction, and bring about psychological and physical changes of the person, which leads to internalized self-change. 


\subsection{Enjoyment realization}

In the fields of general psychology and sports psychology, scholars have tried the rationale for the theory of fun [21][22], a concept that is difficult to define as a function expressed because fun itself is the main factor and can be explored in various situations depending on the individual. In general, fun is the emotion felt during the activity and includes a sense of psychological stability and happiness as an emotional response, and is defined as a state of mind in which the body and mind feel comfortable [23]. Izard, distinguishes fun from sensory-based pleasures, where sensory pleasures, such as sight and taste, form a relationship between sensation and pleasure by direct stimulation, while fun may not be the result of sensory pleasures from such direct stimulation. But the feeling suggests that it is affection and brings pleasure. The reason humans are fundamentally different from animals is to constantly create new needs and try to meet them [24]. Thus, human perceptual fun has strong motivational properties, and the more fun one feels, the more one can maintain social relationships, play an important role in human relationships, and further interact with other emotions or situations [23]. Leisureism has a significant causal relationship with fun [25], suggesting that psychological effects such as acquisition of technology, achievement experience, and stress relief are factors that convey fun [26]. Therefore, a good understanding of the concept of fun should allow individuals to experience a sense of accomplishment and provide them with opportunities for decision-making and choice in various activities [21].

\subsection{Self-realization}

The self was first used by James in the term "ego" or "self" and can be defined as a psychological state, a conceptualized self-assessment in which the feelings, thoughts, attitudes, perception, etc. of individuals interact with each other [27]. Human beings are more than capable of developing, using, and exercising their mental and physical talents and abilities to the fullest extent possible [28] and are commonly used in three meanings: the process of being, the state of being, and belief [29]. And Maslow, who has expanded and embodied the theory of self-realization, is said to be both a human desire and a supreme goal, (Joe, 1992 re-adoption) [30] by fully exercising potential possibilities for individuals. Schultz, [31], who supports Malslow's argument, defines self-realization as a process of self-fulfilling by exercising one's potential in the future and achieving one's ideals. And Buruno, [32] conceptualized it as an effort towards the completion of an organism and an achievement of potential. Meanwhile, in a domestic study, Yoon Pal, [33] defined the inherent potential as realizing the potential of self by fulfilling its calling, invoking humanity, and further achieving valuable tasks. And Jeong Beom-mo, [34] saw that if humans could create their own life worth living and happiness beyond success and failure, that would be self-realization. Kim Jae-woon, [34] said that self-realization is not a lack of self, but a condition to become a human being, and that Kim Dong-Hwang, [35] were self-realization to achieve their own self and further develop and achieve the ultimate goal, not because they lack self-reliance. To sum up the views of various scholars, self-realization is a human effort to move on to the state of being a gentle person for the purposes of education as well as the highest value pursued by human beings.

\section{Research and research design}

\subsection{Setting up research models and hypotheses}


H1. The perception of the ocean, (scuba diving) experience will have a positive, $(+)$ scent for fun perception.

H2. The perceived ocean, (scuba diving) experience will have a positive, $(+)$ scent on selfrealization

H3. Perceived perception of fun will have a positive scent on self-actualization

\subsection{Instrument}

(1) Experience the ocean, (scuba diving)

Ocean experience was defined as a scuba diving experience in confined waters, including a water depth of up to $5 \mathrm{~m}$, and Oh, Fiore \& Jeoung, [36], focusing on measurement items developed based on the theory of Pine \& Glilmore, [37]. Choi Song Hak and Lee Chung-ki, [38] and Seo, Min-jung, [12] modified and supplemented the questions and scales in the experiences used in the study, and composed 12 questions on the Likert 5-point scale.

(2) Recognition of fun

Fun recognition is defined as a positive, $(+)$ emotional reaction that creates interest and creates a satisfactory relationship with others through scuba diving experience in restricted waters. In addition, the scale used in the study by Sang-hoon Park and Rock, [13] was modified and supplemented to constitute 12 questions of the Likert 5-point scale.

(3) Self-realization

Self-realization is defined as the tendency to develop one's own talent or ability and to grow chastity, and the scales used in the research of Kim Jae-won, [39] and Moon Dong-kyu, [40] were modified and supplemented to fit this study, consisting of eight Likert 5-point scales.

\section{Verification of research theory}

\subsection{The marine, (scuba diving) experience will give a positive flavor to Korean- American awareness, (H1)}

Recreational experience, Deviant experience, and Educational experience were found to have a significant positive, (+) effect on Interest, and Deviant experience and Educational experience were not statistically significant on sociability.

Table 1. Multiple regression analysis of scuba diving on the recognition of fun

\begin{tabular}{|c|c|c|c|c|c|c|c|c|}
\hline \multirow{3}{*}{$\begin{array}{l}\text { Independent } \\
\text { variable }\end{array}$} & \multirow{3}{*}{$\begin{array}{c}\text { Depende } \\
\text { nt } \\
\text { variable }\end{array}$} & \multirow{2}{*}{$\begin{array}{c}\text { Non- } \\
\text { standardization } \\
\text { factor }\end{array}$} & \multirow{2}{*}{$\begin{array}{c}\text { Standardization } \\
\text { factor }\end{array}$} & \multirow{3}{*}{$\begin{array}{c}\text { Standard } \\
\text { Error }\end{array}$} & \multirow{3}{*}{$\mathrm{t}$} & \multirow{3}{*}{$\mathrm{P}$ - value } & \multicolumn{2}{|c|}{ Coelastic statistic } \\
\hline & & & & & & & tolerance & VI \\
\hline & & B & Beta & & & & & \\
\hline $\begin{array}{l}\text { Recreational } \\
\text { experience }\end{array}$ & \multirow{3}{*}{ Interest } & .285 & .293 & .078 & 5.224 & $.000 * * *$ & .687 & $\begin{array}{l}1.2 \\
32\end{array}$ \\
\hline $\begin{array}{l}\text { Deviant } \\
\text { experience }\end{array}$ & & .241 & .232 & .068 & 2.368 & $.015^{*}$ & .725 & $\begin{array}{l}1.3 \\
48\end{array}$ \\
\hline $\begin{array}{l}\text { Educational } \\
\text { experience }\end{array}$ & & .194 & .191 & .066 & 2.272 & $.027 *$ & .731 & $\begin{array}{l}1.4 \\
71\end{array}$ \\
\hline
\end{tabular}




\begin{tabular}{|c|c|c|c|c|c|c|c|c|}
\hline $\begin{array}{l}\text { Recreational } \\
\text { experience }\end{array}$ & \multirow{3}{*}{ Social } & .289 & .302 & .072 & 5.577 & $.000 * * *$ & .671 & $\begin{array}{l}1.2 \\
22\end{array}$ \\
\hline $\begin{array}{l}\text { Deviant } \\
\text { experience }\end{array}$ & & .132 & .129 & .068 & 1.527 & .164 & .732 & $\begin{array}{l}1.2 \\
89\end{array}$ \\
\hline $\begin{array}{l}\text { Educational } \\
\text { experience }\end{array}$ & & .128 & .116 & .064 & 1.420 & .176 & .754 & $\begin{array}{l}1.5 \\
19\end{array}$ \\
\hline
\end{tabular}

\subsection{The marine, (scuba diving) experience will give a positive flavor to self-realization,} (H2).

Recreational experience, Deviant experience, and Educational experience were found to have a significant positive, (+) effect on Self-Realization.

Table 2. Multiple regression analysis of scuba diving on self-realization

\begin{tabular}{|c|c|c|c|c|c|c|c|c|}
\hline \multirow{3}{*}{$\begin{array}{l}\text { Independent } \\
\text { variable }\end{array}$} & \multirow{3}{*}{$\begin{array}{l}\text { dependent } \\
\text { variable }\end{array}$} & \multirow{3}{*}{$\begin{array}{c}\begin{array}{c}\text { Non- } \\
\text { standardization } \\
\text { factor }\end{array} \\
\text { B }\end{array}$} & \multirow{2}{*}{$\begin{array}{l}\text { Standardization } \\
\text { factor }\end{array}$} & \multirow{3}{*}{$\begin{array}{l}\text { Standard } \\
\text { Error }\end{array}$} & \multirow{3}{*}{$\mathrm{t}$} & \multirow{3}{*}{$\begin{array}{c}\text { P- } \\
\text { value }\end{array}$} & \multicolumn{2}{|c|}{ Coelastic statistic } \\
\hline & & & & & & & tolerance & VIF \\
\hline & & & Beta & & & & & \\
\hline $\begin{array}{l}\text { Recreational } \\
\text { experience }\end{array}$ & \multirow{3}{*}{$\begin{array}{c}\text { Self - } \\
\text { Realization }\end{array}$} & .281 & .277 & .071 & 5.125 & $.000 * * *$ & .663 & 1.312 \\
\hline $\begin{array}{l}\text { Deviant } \\
\text { experience }\end{array}$ & & .232 & .228 & .067 & 4.124 & $.000 * * *$ & .717 & 1.372 \\
\hline $\begin{array}{l}\text { Educational } \\
\text { experience }\end{array}$ & & .196 & .193 & .066 & 2.351 & $.020^{*}$ & .743 & 1.539 \\
\hline
\end{tabular}

\subsection{Fun perception will have a positive, (+) scent on self-realization, (H3)}

Interest, Sociability, and Recognition were found to have a significant positive, (+) effect on Self-Realization.

Table 3. Multiple regression analysis of interesting perception on self-realization

\begin{tabular}{|c|c|c|c|c|c|c|c|c|}
\hline \multirow{3}{*}{$\begin{array}{l}\text { Independent } \\
\text { variable }\end{array}$} & \multirow{3}{*}{$\begin{array}{l}\text { Dependent } \\
\text { variable }\end{array}$} & \multirow{2}{*}{$\begin{array}{l}\text { Non- } \\
\text { standardization } \\
\text { factor }\end{array}$} & \multirow{2}{*}{$\begin{array}{l}\text { Standardization } \\
\text { factor }\end{array}$} & \multirow{3}{*}{$\begin{array}{l}\text { Standard } \\
\text { Error }\end{array}$} & \multirow{3}{*}{$\mathrm{t}$} & \multirow{3}{*}{$\begin{array}{c}\mathrm{P}- \\
\text { value }\end{array}$} & \multicolumn{2}{|c|}{ Coelastic statistic } \\
\hline & & & & & & & tolerance & VIF \\
\hline & & B & Beta & & & & & \\
\hline Interest & \multirow{3}{*}{$\begin{array}{c}\text { Self - } \\
\text { Realization }\end{array}$} & .262 & .259 & .070 & 4.531 & $.000 * * *$ & .782 & 1.533 \\
\hline Social & & .376 & .364 & .068 & 7.128 & $.000 * * *$ & .645 & 1.397 \\
\hline Recognition & & .214 & .219 & .066 & 3.783 & $.000 * * *$ & .792 & 1.583 \\
\hline
\end{tabular}




\section{Conclusion}

In the leisure and industrial society where interest in marine sports is increasing, this study conducted a study on how scuba diving experiences of middle and high school students have an effect on perception of fun and how it affects their inner development and emotional formation. The summary of the analysis results derived by performing empirical analysis is as follows. First, as a result of verifying $\mathrm{H} 1$ that the marine, (scuba diving) experience will have a positive, (+) effect on fun recognition, (interesting, socializing, and acknowledgment), the sub-factor of the scuba diving experience is statistically related to the interest and recognition of fun recognition. It was found to have a significant effect. However, it was found that scuba diving's sub-factor entertainment experience had a significant effect on fun-aware socializing, and deviation experience and educational experience were not statistically significant. These research results complement the research results of Seo Min-jung et al., [41], and it can be interpreted that the experience, (experience) economic theory can be applied to recognize fun. Second, as a result of verifying $\mathrm{H} 2$ that the marine, (scuba diving) experience will have a positive, (+) scent on self-actualization, it has a significant effect as a statistic and has a significant impact on research and socialization of Lee Sung-bok, [42]. It can be interpreted that these findings have a positive effect on psychological behaviors of marine activities with high achievement after experience compared to activities on the ground. Third, as a result of verifying $\mathrm{H} 3$ that fun perception, (Hungmi, socializing, recognition) will have a positive, $(+)$ direction on self-realization, it has a statistically significant effect. Fun perception of exercise and physical activity affects self-realization. Insane was found to support Kang Seong-il's, [43] research. These findings can be interpreted as having fun awareness through physical activity affecting self-realization, having fun through scuba diving experiences, meeting new people, improving knowledge, and receiving support from one's own abilities.

\section{References}

[1] Hall C. M., "Trends in Ocean and Coastal Tourism: The End of the Last Frontier?" Ocean and Coastal Management, vol.44, no.9-10, pp.601-618, (2001)

[2] Minbo Shim, "Effects of types and experiences of experiences on emotional and behavioral intentions after marine sports experience: focusing on sailing yachts," Ph.D. dissertation, Dong-A University, (2013)

[3] Ministry of Land, "Transport and Maritime Affairs, Ocean. Prepare an activation plan," Department of Maritime Policy, Ministry of Land, Transport and Maritime Affairs, (2010)

[4] Nam dong, "Direction of Korea's maritime development through foreign marine sulfur," Korean policy, (2006)

[5] So hoon, "The effect of the scuba diving leader's perceived literacy on the effectiveness of the leadership trust map," Ph.D. dissertation, Pusan National University, (2012)

[6] Sung-Hong Hong, Sang-Hak Lee, Min-Hwan Kim, and Ki-Woon Kim, "Comparison of changes in lactate CPK amount in scuba diving according to changes in ordination and marine waters," Korean Sports Research, vol.20, no.1, pp.1597-1605, (2003)

[7] Kyung-Ho Jang, Jin-Sang Yoo, Moon-Yeop Oh, and Seong-Duk Jeong, "A case study on the effect of body alignment method by suppressing primitive reflex of cerebral palsy in scuba diving," Korean Journal of Exercise Rehabilitation, vol.7, no.4, pp.121-133, (2011)

[8] So-yong Lee, Gil-soo Han, Moon-Yeop Oh, and Myeong-hak Kang, "The effects of repeated diving on epinephrine and norepinephrine dopamine in scuba diving environment according to scuba diving experience," Korean Journal of Physical Science, vol.25, no.1, pp.1157-1167, (2016)

[9] Lim Woo-Hun Kwon, "Narrative exploration of scuba diving leadership curriculum experiences," Korean Journal of Physical Education, vol.51, no.5, pp.527-535, (2012) 
[10] Sohoon, Yoojo, and Hwangseong, "Analyzing the relationship model of scuba diving leader's literacy and leadership trust leadership effectiveness," Fisheries and Marine Education Research, vol.27, no.5, pp.14361446, (2015)

[11] Dong Wook Kim and Gap Kim, "The relationship between participation level of scuba diving participants and participation motivation happiness," Journal of Korean Society of Physical Education, vol.48, no.1, pp.581-591, (2012)

[12] Minjung Seo, “The effects of marine sports participants' experiences on emotion, memory, satisfaction, and loyalty: Comparison of domestic and foreign diving activities," Ph.D. dissertation, Sejong University, (2012)

[13] Sanghoon Park and Rock, "The effects of marine experience on fun factors and behavioral intentions-focused on scuba diving," Tourism Research, vol.39, no.3, pp.25-43, (2014)

[14] Kwon Jae, “Topology Academy,” Seoul: Beopmunsa Temple, (1974)

[15] Guo, “A plan to develop Busan's marine sports prepared for the Asian Games in 2002," Dongeui University Sports Science Journal, $3^{\text {rd }}$, (1996)

[16] Korea Industrial Research Institute, White Paper 2006. Seoul: Korea Research Institute, (2006)

[17] Ki Hyun Lim, "A study on the present condition and strategy of marine sports industry of Korea," Korean Society of Sport Management, vol.24, no.6, 80-92, (2019)

[18] Dong Woo Ko, "The relationship between psychological experience and satisfaction," Ph.D. dissertation, Korea University, (1998)

[19] Sungshin, Dongwoo Woo, and Jeongho, "Psychological essence of leisure experience: What is fun?" Consumer Studies, vol.7, no.2, pp.35-57, (1996)

[20] Je Eun Lee and Kong Kim, "An Analysis of the Relationship between Interest and Worry in Lessons," Satisfaction with Lessons, and Intention on Athletics Continuity Korean Journal of Physical Education, vol.22, no.4, pp.63-83, (2013)

[21] Deci. E. L. and AMP Ryan M. R., "Intrinsic motivation and self-determination in human behavior," NY.: Plenum Press, (1985)

[22] Scanlan T. K. and AMP Simons J. P., “The construct of sport enjoyment,” In G. C. Roberts (Ed.), Motivation in sport and exercise, Champion, IL.: Human Kinetics, (1992)

[23] lzard, C. E., "The psychology of emotions,” New York.: Plenum, (1991)

[24] Hye-gon Lee and Kyeong-rok Oh, "The effects of elementary school students 'after-school physical activity participants' fun factors on physical education recognition and movement intention to continue," Korean Journal of Physical Science, vol.22, no.3, pp.669-682, (2013)

[25] Jeong Ho Jeon, "The effects of fun factors on leisure satisfaction and leisure flow of sports center members," Korean Journal of Sports, vol.18, no.1, pp.227-237, (2020)

[26] Seong-soo Baek and Chang-hoon Seong, "Fun promotion factors and impediments to middle school physical education classes," Journal of Korean Society for Sports Education, vol.7, no.2, pp.99-116, (2000)

[27] Sang-Ryong Kim, "The relationship between student participation in leisure and recreation, stress, and selfesteem," Ph.D. dissertation, Graduate School of Target University, (2009)

[28] Min Jin, "Tissue treatment characteristics and self-achievement," Ph.D. dissertation, Seoul National University, (1986)

[29] Ha Heon-seon, "A study on the influence of the motivation of school teachers on perceived values, selfefficacy, and job satisfaction self-realization," Ph.D. dissertation, Woosong University, (2012)

[30] Joe, "Understanding and self-realization of human behavior," Seoul: Muneumsa Temple, (1992)

[31] Schultz D, "Growth psychology: Models of the health personality," New York: D, Van Nastrand Company, (1977)

[32] Buruno F. J., “Adjustment and Personal Growth,” 2nd Ed, New York: John Wiley \&AMP; Sons, (1983)

[33] Yoon Pal, "Exploring the theory of the human psychology curriculum: The education of self-realization," Ph.D. dissertation, Seoul National University, (1980)

[34] Bummo Jeong, "Human self-realization," Seoul: Nanam Corporation, (1997) 
[35] Kim Dong-Hwang, "A study on the relationship between leisure satisfaction and self-realization according to the lifestyle type of leisure activities," Research, vol.27, no.2, pp.39-60, (2012)

[36] Oh H. Fiore, A. M. AMP; Jeoung M., "Measuring experience economy concepts: tourism applications," Journal of Travel Research, vol.46, no.2, pp.119-132, (2007)

[37] Pine B. J. and AMP Gilmore J. H., "Welcome to the experience economy," Harvard Business Review, vol.76, no.4, pp.97-105, (1999)

[38] Song Hak Choi and Lee Chung Ki, "A study on the loyalty of festival visitors based on 4Es theory: focusing on the Boryeong Mud Festival. Research, vol.25, no.6, pp.179-198, (2011)

[39] Jae woon Kim, "The relationship between teacher's participation in sports-type leisure activities, teaching stress, and teaching satisfaction," Ph.D. dissertation, Seoul National University, (2004)

[40] Dong-Kyu Moon, "The relationship between youth's participation in leisure sports, immersion experience, and self-efficacy," Ph.D. dissertation,, Graduate School of Mokpo National University, (2007)

[41] Dong Wook Lee, "The structural relationships analysis on scuba diving resort customers perceived lifestyle and selection attribute and loyalty," The Korean Society of Sports Science, vol.28, no.5, pp.463-475, (2019)

[42] Sungbok Lee, "The effects of skin scuba program on self-assistance and attention concentration response behavior of autistic people with disabilities," Ph.D. dissertation, Pusan National University, (2014)

[43] Seong-il Kang, "Design of fun factors and leisure satisfaction self-realization according to the immersive experience of extreme sports participants," Ph.D. dissertation, Korea Physical Education Academy, (2010) 